\section{PORTUGAL AT THE EYE OF THE STORM: CRISIS, AUSTERITY AND THE MEDIA}

HELENA SOUSA LUÍS ANTÓNIO SANTOS

\begin{abstract}
The governmental change which took place in Portugal after 2011 was far more than just a new episode in the typical rotation between the two major political parties given that it occurred whilst the country was initiating a three year period of external financial control. As such the three political forces actively engaged in this rough transition have consistently pursued a stern austerity strategy imposed

by creditors. This uneven platform (shaped by submission rather than by accord) has been the breeding ground for a discourse centred on the existence of a broad national consensus in support of the adopted draconian austerity measures. Irruptions of dissent have been met with contempt and have been dismissed as self-interested opinions

or even as anti-patriotic. This article has four main parts. In the first one, the fundamental features of the economic and financial crisis and its consequences will be presented. In the second part, the political impacts and challenges of the crisis will be scrutinised. The political and economic impact is closely articulated with the current situation of mainstream media that is presented in the third part of the paper. As we will see in the last part of this article, a particular combination of factors in a country without financial sovereignty has created the perfect conditions for media reproduction of the government and creditors' discourses.
\end{abstract} Helena Sousa is Professor at Communication and Society Research Centre, University of Minho; e-mail: helena@ics.uminho.pt.

Luís António Santos is Lecturer at Communication and Society Research Centre, University of Minho, e-mail: Isantos@ics.uminho.pt. 


\section{Introduction}

The governmental change which took place in Portugal after 2011 was far more than just a new episode in the typical rotation between the two major political parties given that it occurred whilst the country was initiating a three year period of external financial control by the troika (European Commission, European Central Bank and the International Monetary Fund). The socialists negotiated the financial package having already resigned and the social-democrat lead coalition was voted into power on the basis of promises it could not keep (namely on taxation, salaries, and pensions). As such - even when efforts were made to create a separation between them - the three political forces actively engaged in this rough transition have consistently pursued a stern austerity strategy imposed by creditors. This uneven platform (shaped by submission rather than by accord) has been the breeding ground for a discourse centred on the existence of a broad national consensus in support of the adopted draconian austerity measures. Irruptions of dissent have been met with contempt and have been dismissed as self-interested opinions or even as anti-patriotic.

The mainstream media's adhesion to this government fuelled discursive construct owed as much to traditional dependencies between media and power structures - in November 2012 the Prime Minister, Passos Coelho, would remark that journalists should shy away from a "sickening debate" on "what might go wrong"1 - as it did to three interconnected and overlapping processes: problems derived from mounting challenges arising from digitalisation, the effects of the financial crisis itself on media revenues, and the changes in their property and management structures ensuing the steady entry of Angolan capital.

For these reasons mainstream media's attention has not strayed from a fundamentally inward looking focus - even in the usage of external references to Portugal's situation - hence being on the whole unable to open up space for broader debates on mid and long terms European options.

This article has four main parts. In the first one, the fundamental features of the economic and financial crisis and its consequences will be presented. In the second part, the political impacts and challenges of the crisis will be scrutinised. The political and economic impact is closely articulated with the current situation of mainstream media that is presented in the third part of the paper. As we will see in the last part of this article, a particular combination of factors in a country without financial sovereignty has created the perfect conditions for media reproduction of the government and creditors' discourses.

\section{Recipe for Disaster}

"There is probably nothing more difficult to explain in our [Portuguese] economic policy over the last four or five decades than the decision to join the Euro," says João Ferreira do Amaral, a professor of Economics and a long standing critic of the Eurozone, in the book "Porque devemos sair do Euro"2 (2013, 93). Like others opposed to the Euro and the end of the monetary independence with the disappearance of the national currency, Amaral says that the country has lost the possibility of correcting external imbalances based on currency depreciation and links this to some other misconceptions that created a consensus around the Euro in the 1990s (2013). 
One misconception was the idea that a single currency would provide the Portuguese economy with a protective umbrella against global financial instability. This was clearly a misguided perception of the European Institutions as their subsequent functioning has embodied a neo-liberal programme and diverged away from any progressive "Social Europe" or European "community" agenda, orientated towards the defence of human rights, social cohesion and full employment $(2013,93)$.

Moreover, the Eurozone has destroyed the nation-states' well-established stabilising economic mechanisms and has forced less competitive economies to operate under the rules of a strong currency and policies designed to serve interests of the locomotive of Europe, Germany. The Eurozone did not protect peripheral countries as surplus capitals from Central and Northern economies have flooded the country due to low interest rates and intense external push for credit taking. In the mid-1990's the Portuguese families and companies were below the European average in terms of indebtedness levels but the institutional "official optimism" actively promoted credit-taking and invigorated the banking sector.

The second relevant misconception developed around the notion that Eurozone institutions were created to provide extra credibility and reputation to the European monetary institutions. Contrary to many prior claims, low interest rates did not prove to provide any singular benefit or blessing. The influx of credit has coincided with the expansion of markets globalisation, which had a dramatic impact in Portugal. Being a less sophisticated economy, its more traditional exports (e.g. textiles) collapsed under the pressure of emerging economies such as China. The enlargement of Europe to Eastern European Countries (with low wages and high qualified labour force) has also created additional difficulties to the Portuguese exports. In this context, the low interest rates capital did not serve the country's external competitiveness but the expansion of internal consumption and non-tradable products such as housing and services. The economy became reliant on imports and services fuelled by the expansion of easy credit.

Indeed, as Rodrigues and Reis $(2012,191)$ point out, the co-existence of credit-led and export-led models of growth in Europe "ultimately led to the creditors gaining the upper hand against divided debtors," imposing deflationary policies that increase unemployment, the probability of defaults, and the possibility of ever greater political tensions. So, when the financial and economic crisis became shockingly evident in 2008, the fractures between core and periphery in Europe became even more obvious. The European institutions, led de facto by Germany, defended the interests of the financial institutions and the crisis has been dealt with via the socialisation of debt and "adjustments" in the labour market. For critics such as Rodrigues and Reis $(2012,189)$, one core problem is that the Euro comprises "a currency without a sovereign state on the same scale" and this means that there is little capacity for managing imbalances or tensions in a way that avoids "turning labour and social conditions into the main variables of adjustment to crises" (Rodrigues and Reis 2012,189). This is precisely what has happened in the Portuguese case.

The already difficult economic situation deteriorated rapidly during the most acute phase of the financial crisis from 2008 to 2010. Unable to cope with a mounting public debt and market speculation, the socialist government led by José Sócrates announced severe austerity measures in 2010 (taxes, cuts in public services, etc.) to reduce the state deficit that had reached 9.4 percent in 2009 , one of the highest in 
the Eurozone. Under national and international pressure the socialist government did not resist as one of the proposed austerity packs (the 4th Stability and Growth Program) was not approved by Parliament on March 2011. In these circumstances, José Sócrates resigned paving the way for the troika intervention in yet another European country.

This external intervention from the troika was enthusiastically supported by the right-wing parties that gained a Parliamentary majority in the 2011 elections (Social Democratic Party and Popular Party). Despite the profound differences between Portugal, Greece and Ireland (and the nature of their economic problems), the recipe was basically the same: rapid budgetary adjustment, labour market flexibilisation, changes in the housing market, cuts in social provisions and privatisation of state property. The May $2011^{3}$ Memorandum of Understanding was framed by the governing parties and by the media as "foreign help" to the Portuguese state as we will demonstrate later in this article. In mainstream media and political discourse, there was an overarching consensus regarding the need of this "help" and there was a popular belief that this "support" would bring about better living conditions. During the electoral campaign, the present-day (2014) Prime Minister, Pedro Passos Coelho, promised that salaries would not be cut and taxes would not be increased. The opposite has happened and severe austerity measures were implemented.

The administration of this remedy was profoundly violent for the vast majority of the population. The March 2014 report of the National Statistics Institute ${ }^{4}$ concerning "Income and Living Conditions" says that in 2012, 18.7 percent of the population (around 2 million) live below the poverty line with a monthly income of $400 €$ or less. This is the highest level since 2005 and it represents an increase of 17.9 percent compared to 2011. Another concerning poverty indicator relates to families with children. According to INE (24 March 2014, 1), the poverty risk is particularly acute for mono-parental families with one child (33.6 percent) and families with two adults and three or more children (40.4 percent). These cold figures explain news about children who fainted at school due to malnourishment and it also partly explains the increasing efforts of school communities and civil society associations to provide food in various ways for children and their families even during holiday periods.

The latest report on living conditions however does not merely speak about the impoverishment of the population. Indeed, not everybody's situation is getting worst. Some of the biggest economic groups such as Jerónimo Martins and Sonae (Jornal de Negócios, ${ }^{5} 25$ February 2014; Público, ${ }^{6} 19$ February 2014) saw their profits rocket from 2012 to 2013. According to the President of AMI (Assistência Médica Internacional), Fernando Nobre, the situation is alarming: "over the last year the 100 richest persons in Portugal saw their fortunes increase by a 1/3" (in Diário Económico, 76 March 2014).

Poverty is inexorably linked to unemployment, the most dramatic development of this sovereign debt crisis. Portugal's unemployment was 3.9 percent in 2000 and it increased steadily ever since hinting at the structural difficulties of the economy within the Eurozone. In 2010 (with austerity measures already in place but without the troika), the figure went up to 10.8 percent and it has expanded steadily since then: 12.7 percent in 2011, 15.7 percent in 2012 and 16.3 percent in 2013..$^{8}$ According to INE, in the last three years of official figures (2010, 2011 and 2012), 563.000 jobs 
were lost. ${ }^{9}$ In 2012, young people (aged 25 to 34) were the most affected in terms of job losses. ${ }^{10}$

Poverty, unemployment, job insecurity are profoundly linked with the massive migration of highly qualified young people to European countries, Angola, Mozambique, Brazil and other destinations. This is the biggest outgoing flow of Portuguese population since the 1960s when the authoritarian regime led by Oliveira Salazar ruled the country. It is estimated that since 2008, more than 100,000 people left the country every single year. According to INE demographic figures, in 2012, 51,958 people left the country for more than a year (long term migrants) and 69,460 left the country for a period between 3 months and 1 year (temporary migrants) (INE, 2013). For a country of 10 million people, the migration of more than 100,000 people per year (mostly young and educated) is bound to have a major impact on its future prospects. This outflow is not in any way compensated by an non-national population influx (for more, see INE 2013). Concomitantly from 2001 to 2012, the birth rate in Portugal has steadily declined. The latest official figures (2012) show that this decline has reached an historic low of 89,800 births per year, the smallest figure since the year 1900 (INE 2013, 38).

Thus in summary terms, migration, unemployment and the unprecedented reduction of social rights are the most obvious signs of the so-called "adjustment" process and such fundamental shifts imply a structural change in societal power relations. In 2014, poverty has increased whilst the public debt has expanded to a record 129 percent of the GDP. The politicians' discourses on the success of the troika intervention and heroic adjustment of the country are struggling with reality as the vast majority of the population perceives it.

\section{Institutions against Citizens}

The Memorandum of Understanding ${ }^{11}$ signed in May 2001 by the troika and the Portuguese state, namely by the outgoing Socialist Party and the incoming centre-right government parties (Social Democratic Party and Popular Party) is the centre-piece of the austerity policy. Under fierce market speculation and struggling to avoid bankruptcy, the country handed out its sovereignty and asked for a financial "rescue" programme. The $€ 78.000$ million loan programme was attached to austerity measures encompassing all governmental sectorial areas from fiscal policies to education. Financial assistance was made subject to quarterly reviews to be carried out between the first quarter of 2011 and (the 12th and last) the second quarter of 2014.

As in other EU states, this detailed Memorandum of Understanding sets out very specific targets for reduction of state expenditure and revenue increase, namely through the "sliming" of the state's functions and social security provisions and the generalised and substantial hiking of taxation. Moreover, the document describes the privatisation programme naming the companies that should be privatised. The labour market and education are thoroughly inscribed in the document well in line with the neo-liberal frame that underlines the programme: flexibilisation of labour conditions, precariousness, cuts in unemployment benefits, matching human capital with labour market.

The social democrats - which took power in the June $5^{\text {th }} 2011$ elections - have used the memorandum as part of the electoral strategy putting the programme 
under a constructive light. The enthusiasm for the programme was such that the elected Prime Minister publicly said that the State would be able to "go beyond the Troika" (Público, 6 June 2011). Pedro Passos Coelho explained that the country did not wish to be a "burden to (our) partners" and therefore it would do "whatever necessary" to fulfil all commitments and "regain the trust of the markets" (Diário de Notícias, ${ }^{12} 6$ June 2011).

Despite the signing of the Memorandum of Understanding, the Socialist Party (led by António José Seguro between the 2011 legislative elections and late 2014) soon started to drift away from subsequent policy initiatives. The socialists favoured a different path to fulfil the Memorandum's objectives. Still, their role has been quite ambiguous given that any serious attempts to further distance themselves from the austerity measures has been met with an effective two-pronged accusation: they were the ones who signed the agreement with the external entities and they were the ones who lead the country to a situation whereby assistance was inevitable.

However simplistic these arguments may seem the fact is that for the most part they have been sufficient to paralyse the socialists, the biggest opposition party, hence creating the notion of a broad consensus amongst the three main parties of the so-called "arch of power" (the Popular Party, the Social Democratic Party and the Socialist Party). Openly alternative thinking in Parliament could only be found amongst the two leftist parties: Bloco de Esquerda (Leftist Block) and the Communist Party, both of them not truly perceived as governing alternatives.

The "manufacture of consent," to use the famous notion of Walter Lippmann (1922/2012) has not been promoted merely by the governing parties with the complacency of the Socialist Party and the mainstream media. The President of the Republic, Aníbal Cavaco Silva, has been a key figure in the process. Despite some initial hesitancy, Cavaco Silva has more recently been voicing a strong defence of the troika measures and the inevitable deepening of austerity in the post-troika period, that is, after 2014. In March 2014, he has published a Preface of Roteiros $V I I I^{13}$ where, once again, the Portuguese people were asked to remain peaceful, accepting the inescapable payment of the public debt in full, along an arduous path to be undertaken at least until 2035.

Furthermore, this impetus to promote a wider political consensus has also enlisted the President of the European Commission until late 2014, Durão Barroso (a Portuguese himself) who has often argued for the need of a post-troika governing arrangement between the three "arch of power" parties (Expresso ${ }^{14} 29$ March 2014, 8).

According to this discursive frame, the Portuguese people are suffering the austerity measures because they have not been financially responsible in the past and should in the future behave along the lines of the Germans: "Instead of criticizing Germany, let's do what Germany has done. It has reformed itself and today the country can be tranquil. Portugal has a fantastic opportunity to become a modern country, to transform this crisis into an opportunity" (Barroso in Expresso 29 March 2014, 8).

Whilst high office politicians incessantly advocated meekness in face of inevitable austerity measures, signs of resistance began to emerge namely through recurrent street protests. To a growing number of people it became difficult to absorb the rationale behind a statement like the one made by the Parliamentary leader of the Social Democratic Party, Luís Montenegro: "people's lives are not better but 
the country is." 15 The schizophrenic division between the "people," living in worst conditions, and the "country" that is, in Luis Montenegro's view, performing better (the trade balance has improved and interests rates are lower) sheds light onto the understanding of a political system whose central axis has shifted away from the community that it is supposed to represent.

Not surprisingly, the gap between government (and political parties) and citizens has been widening, as politicians seem gradually detached from everyday difficulties. In addition to the more notorious public demonstrations (mostly orderly), the popular distrust can also be discerned in the electoral success of independent candidates in the 2013 local elections. Around 7 percent of the local government independent candidates won seats. ${ }^{16}$ The vice-president of the National Association for Independent Local Government Movements, Maria Teresa Serrenho, considered that the increase in independent seats reflected the "desolation of citizens" with the political apparatus. ${ }^{17}$ Even if political analysts have pointed out that some independent candidates result from internal party divisions, the victory of non-partisan candidates demonstrates that parties themselves were not understood as a critical backup for those candidacies. Independent candidates, for example, now run important cities such as Oporto and Matosinhos.

The mainstream media replication of the official discourse didn't help citizens to decode the reasons behind the dramatic changes taking place in their lives. However, a more informed and intellectually sophisticated consensus has been evolving in the Portuguese society around the recognition that austerity measures are aggravating (not solving) the economic problems themselves and that the external public debt needs an efficient restructuring process. On the 12th of March 2014, 74 well known personalities from the most diverse ideological backgrounds came to the fore with a Manifesto "To prepare the debt restructuring for a sustainable growth" (in Público 12 March 2014, 4-6). The 74 personalities included economic advisors to the President of the Republic, former finance ministers from different political sensibilities, representatives of both labour and business associations, academics, intellectuals and others.

The main argument of these 74 personalities is that the response to the present-day crisis cannot succeed without addressing the public debt in articulation with the economic growth and job creation within a framework of cohesion and effective solidarity (in Público 12 March 2014, 4).

The Manifesto has unleashed a massive negative response from the government and opinion makers alike. The President of the European Commision, Durão Barroso, has also come to the fore to criticise two former finance ministers from social democratic-led governments, Manuela Ferreira Leite and Bagão Félix, for having signed the Manifesto (Expresso 29 March 2014: 07). He has explained their decision to sign the Manifesto as a result of the loss of income they had personally suffered: "both Manuela Ferreira Leite and Bagão Felix represent a certain middle-class that lived relatively well but they were hit by this situation" (Expresso 29 March 2014, 7)

In the words of Manuel Carvalho, the irritation the Manifesto has caused is the best proof of its relevance and success: "For once, Portugal is debating its future outside the frame imposed by the government. For a moment, one is back to the political debate only to realize that there is life beyond the official truth and the conditioned debate by the markets susceptibilities" (Carvalho in Público 16 March 2014). ${ }^{18}$ 


\section{Fragile Mainstream Media}

In late March 2014 a Portuguese junior minister asked a group of selected journalists to attend a private briefing at the Finance ministry on pensions and civil service pay cutbacks planned for 2015. The journalists all agreed to use comments made in that room without quoting the source ("official ministry source" was the preferred formulation) and to respect a specific time embargo. When the "news" was eventually published the prime minister himself promptly dismissed it as "noise" and as "manipulation" and two distinct senior ministers referred to it as no more than "speculation."19 The editors of the seven media outlets, whose reporting had been put into questioning, immediately issued a joint statement guaranteeing that their journalists abided by the formal agreement jointly made with the junior minister. ${ }^{20}$

This brief summation of what naturally was a far more intricate affair is brought forward as an example of the current frailty of editorial decision-making in Portugal; journalists increasingly accept a diminished role in the news-worthiness framing of the agenda, and increasingly accept a role as conduits of governmental "testing-the-waters" communication strategies (Maarek 2007). The seven media outlets which have accepted to play an active part in what has eventually surfaced as a botched spinning manoeuvre are simply the country's most important dailies (Correio da Manhã, Jornal de Notícias, Diário de Notícias, and Público), the national news agency (Lusa), and two very relevant economic publications (Diário Económico and Dinheiro Vivo).

If we were thus to look upon this with the useful conceptual contribution of Hallin we would note that on this particular issue the bulk of media production veers away from a "sphere of legitimate controversy" privileging instead a "sphere of consensus" one (1986, 116-117). Yet, unlike the situation lived by American journalists after September 11, in which "they felt connected and important to their audience (...) they felt appreciated as they rarely do" (Schudson 2008, 82-83), the consensual "we" appears in this instance to connect them to political and economic elites rather than to their audience.

The Portuguese media's pre-emptive efforts to disclose the potential problems of ailing national banking institutions, of stressed real estate markets or of struggling public accounts in the first years of this century were not very adamant (with a very few notable exception ${ }^{21}$ ) and the "sudden" appearance of a crisis from 2008 onwards dented credibilities. The media responded by substantially increasing attention to financial and economic topics whilst adopting a stance that promoted notions of national guilt and the ensuing necessity to "pay our dues." In an assessment of journalistic performance before the crisis, the Economy editor of a national TV channel, Luis Ferreira Lopes, would write: "in the future we must all act faster (...) the issue of trust is increasingly more important for the banking business but also for the TV business" $(2009,41)$.

A recent study analysing the main news bulletin of a national TV channel, SIC, between 2007 and 2011, noted that two categories - "financial crisis" and "economy and business" accounted for 68.4 percent of all the news stories and that in 28.9 percent of those bulletins they were given opening status. "Financial crisis" occupied in 20071.4 percent of the total time of the bulletins and by 2011 it accounted for 8.7 percent of the total time (Fragoso 2013, 99-107). 
The perceived lack of valuable information thus gave way to an overflow of information; suddenly households were surrounded by news regarding rating agencies, the "weight" of national debt - often presented through the "each Portuguese owes X to foreign creditors" formula - subprime or toxic investments. From 2010 onwards the mainstream media increasingly confronted the eroded minority socialist government voicing both political opposition concerns and social uneasiness resulting from the first austerity measures. It would later emerge that a significant part of that shift was linked to a deliberate effort - in both specific media outlets but also in digital environments, like blogs and social networks - to promote the profile of the social democrat alternative to government (Carvalho 2013). ${ }^{22}$

The excessive proximity between a newly elected majority government and mainstream media is not exactly a novelty within the Portuguese political context (Cunha 2013, 25). That should however neither keep us from noting the particularities of the current situation nor from equating them in the context of a broader analysis of media discourse surrounding the on-going financial and economic crisis.

Indeed, Portuguese mainstream media's endeavours to reverberate the existence of a broad national consensus on key aspects of the government's strategy to deal with the crisis - the semantic preference for "savings" in lieu of "cuts," the emphatic usage of specific frames like "the overgrown/fat State," "the unmanageable social security system," or the "rationalisation of services," the deliberate increased profile given to financial related themes and actors, the de-personalisation of national creditors (mostly mentioned as "financial markets" or "investors"), and also the active involvement of journalistic national household names in the publication of books with titles like "Enough!," "Get out of the way!"” or "My government programme" - result from a very peculiar combination of debilitating processes of change affecting the media.

The first of these processes is what might broadly be described as Portuguese media's poor handling of the digitisation induced transformations occurred since the beginning of this century.

Although some of the major media outlets did manage to have an online presence in tandem with internationally known operations (the first recorded presence, Jornal de Notícias, occurred in 2005) very few steps were taken to evolve past a shovelware strategy (Bastos 2010) and most significantly a severe undervaluation of the internet's potential for the creation of thematic information driven outlets and for autonomous small ad spaces resulted in an overall erosion of audience and revenue.

It should in fairness be pointed out that most Portuguese media groups emerged only in the 1990's and their primary goal in the first years of existence - adhering to an EU vision of media centred on economic rather than socio-cultural interests (Michalis 2011) - was to respond to the challenges of an overproduction and increasingly deindustrialisation scenario already under way in other countries (Meyer 2004; Brock 2013). The impetus was directed at platform convergence initiatives (sometimes cooperative and sometimes competitive) in order to reduce costs. At the heart of some of these changes were news production reformulations with profound labour relations impacts, like the alteration of job descriptions, working schedules and payment structures. This in turn favoured the beginning of the externalisation of services and the increased dependency on freelancers and interns (Garcia 2010). ${ }^{23}$ If anything the ensuing financial and economic crisis only accentuated the corrosive effects of these measures on journalistic production. 
The second process is the context of financial and economic crisis itself. The disappearance from the Portuguese economy of an estimated $29 \mathrm{~B} €$ (resulting from imposed austerity measures) between 2011 and $2015^{24}$ naturally had a severe effect on internal consumption indexed activities like advertising and media content production, compounding a debilitated situation which had been noted at least since 2004. In the timeframe of a decade - 2004 to 2013 - the Portuguese advertising market was cut by nearly half (from $720 \mathrm{M} €$ in 2007 to $390 \mathrm{M} €$ in 2013) and the combined revenues of the three publicly traded Portuguese media groups (Impresa, Media Capital and Cofina) were cut by 35 percent. These three groups suffered losses of $80 \mathrm{M} €$ in 2008 and $29 \mathrm{M} €$ in 2011, partially offset by gains of $11 \mathrm{M} €$ in 2012 and 25 M€ in 2013 (Nobre 2014).

A comparative study of the share value of 29 media groups listed in the stock markets of Greece, Portugal, Ireland, Italy and Spain between 2007 and 2012 found that the average loss of value exceeded 20 percent. Portugal's groups performance was as follows: Impresa's value decreased 85.51 percent, Media Capital's decreased 80.5 percent, Zon's decreased 63.51 percent, and only Cofina's rose by 43.9 percent (Fernández 2013,121).

According to the Portuguese circulation association (APCT) between 2008 and 2013 the overall circulation of the main national newspapers declined substantially; Correio da Manhã lost 3.85 percent, Diário de Notícias lost 49.94 percent, Jornal de Notícias lost 34.16 percent, Público lost 37.13 percent and the main weekly, Expresso, lost 20.89 percent. $^{25}$

Facing a severe decrease in advertising revenue and an accentuation of a tendency for audience loss, debilitated media groups have been forced to "talk about restructuring without liquidity" (Fernández 2013, 122) enhancing convergence/ cost reduction initiatives and favouring content strategies less devoted to the more expensive production of hard news and much more in tune with an attention to entertainment spirit (Campos-Freire 2011).

The third process relates to Portugal's colonial past and it results from the propitious combination between the severe short-term financial difficulties of the major media groups and the notable investment interests of the Angolan political and economic elite.

The notion that this restricted elite should take it upon themselves to hasten a "primitive accumulation of capital" - as explained by the President, José Eduardo dos Santos, in a "State of the Nation" address to Parliament in October 2013 (Santos 2013, 13) - had been promoted internally since 2002 and its expansion and diversification rationale targeted Portugal's ailing building, real estate and banking businesses as apt investment opportunities from 2007 onwards.

The newfound proximity, between penurious businesses of a former colonial power and the ebullient elite of a former colony was actively promoted by a broad spectrum of Portuguese politicians, some of them eventually being deemed appropriate to integrate managing boards or advisory boards in the existing or newly founded companies (Costa et al 2014, 97-101). ${ }^{26}$

The presence of Angolan capital in Portuguese media groups began in 2009 and has been growing steadily ever since. In the absence of a single clear cut explanation for the strategic combined entry of several formally distinct Angolan entities a few signs should be highlighted; first and foremost, Angolan investments in the Portuguese banking sector implied the acquisition of a creditor position with indebted 
Portuguese media groups; secondly, media production on mutual interest matters has always been perceived by both countries (at least by both countries elites') as very relevant, sometimes in a somewhat over-sensitive manner. ${ }^{27}$

The intricate web of relations created by Angolan capital in Portugal between the interests of those closest to the economic and political elites on both countries added content frailty to an already debilitated sector. These acquisitions have no doubt played a role in both the increased prominence of overtly positive narratives about Angola and its entrepreneurship but also in the disappearance (or marginalisation to autonomous websites) from the media agenda of dissenting voices.

By the same token, selective changes in managerial boards and even editorial leaderships ensured the maintenance of a less than hostile stance towards the current Portuguese government. Going back to the seven media outlets quoted earlier it should thus not be surprising to say that five of them belong either to Cofina or Controlinveste, both now controlled by Angolan capital.

\section{Hopeless Mainstream Discourses}

In November 2012 the New York Times published in the Europe section of its international news site a photographic gallery entitled "Portugal passes another austere budget." Each of the 17 black and white photos tells an individual story of strife against the consequences of the crisis; under an image of Rosa Serra Pereira, a middle-aged woman who lives in a small Lisbon apartment with six dependents, we can read: "In Portugal, austerity means that hospitals are closing, and state benefits, public wages and pensions are being cut. New taxes have been added and old taxes increased." Under a photo of homeless men gathered outside a church where free food is distributed we read: "The government had been winning praise from international lenders who last year negotiated a bailout worth about \$101 billion, following similar deals with Greece and Ireland."28

Having been presented just two weeks after a major general strike, which joined Portugal and Spain, this news feature - described by the most influential weekly, Expresso, as a bleak portrait of the country ${ }^{29}$ - had a considerable impact, to the point of being mentioned by politicians and political commentators alike.

Especially from 2011 onwards news produced by foreign media about Portugal's financial, economic, and social situation generally became very relevant to internal political discussions. A country with diminished sovereignty, ruled by a very compliant government with the acquiescence of a debilitated mainstream media developed a necessity - on different sides of the political and social debates - to seek out some sort of reassurance in those external reports. As such, news about the overall governmental success in attaining the goals jointly set out with the troika would naturally become as useful in the defence of the adopted strategy as much as news prompted by less favourable descriptions of Portugal's dire situation would fuel opposition claims for a significant policy change.

Most favoured by both camps would become the opinions of internationally reputed economists - Nobel laureates acquiring a rather special status. Paul Krugman, for instance, devoted some of his New York Times columns to Portugal from 2011 through to 2013, with a very significant impact. In January 2011 he would "announce" that Portugal would be "the next eurodomino," 30 a few months later he would state that Greece, Ireland, and Portugal "would not be able to pay their 
debts in full," ${ }^{11}$ and roughly a year later, on receiving a Honoris Causa Doctorate from Lisbon University, he would add that Portuguese salaries should devaluate some 30 percent. ${ }^{32}$ By May 2013, under the heading "Nightmare in Portugal," the 2008 Nobel laureate would reflect on a dire portrait of the country published a few days earlier by the Financial Times by saying: “Don't tell me that Portugal has had bad policies in the past and has deep structural problems. Of course it has; so does everyone, and while arguably Portugal's are worse than those of some other countries, how can it possibly make sense to 'deal' with these problems by condemning vast numbers of willing workers to unemployment?"33

Portuguese mainstream media attention has thus not strayed too far from an excessive inward looking focus, capturing into the discourse on the crisis most relevant external references to the country and recuperating, in a peculiar manner, traces from a self-doubting discourse on the worth of the nation first enunciated more than a century ago (Queirós and Ortigão 1873/2004, 312).

Notable exceptions to this predominance were references to other European countries in difficulties (PIIGS) - especially the broad "we are not like Greece" topic - the election of François Hollande for the French Presidency in May 2012 (given the perception that it would soften Germany's overbearing influence in European financial and economic decisions), European Central Bank policy decisions, and EU summits where common strategies to deal with the crisis have been debated (namely the topic of debt mutualisation). Discussions on broader issues of European policy and especially debates on other than short-term alternatives have been on the whole side-lined from mainstream media, finding their way into thematic programmes on cable TV news channels or into sparse items on specialised business newspapers/magazines.

This peculiar take on events and the apparent lack of attention to larger forward looking strategies for the EU is, however, not a great departure from what had happened in pre-crisis years. Indeed Portugal has always been portrayed by mainstream media (and perceived by most citizens) as a peripheral country allowed to enter a special group at the expense of some part of its sovereignty. Europe has, in that sense, traditionally been much more of an external entity with increasing power over national affairs (and indeed daily life) than as a "part of us."

\section{Concluding Remarks}

In this article we tried to clarify the fundamental features of the economic and financial crisis in Portugal and its socio-political consequences. We have seen how deeply the crisis has affected common people with a dramatic increase in poverty, unemployment and migration. Some dimensions of the crisis are more difficult to measure and to demonstrate with figures but there are numerous reports and statements from state officials and academics alike, which highlight the increase in suicide rates, the increase in medicine consumption (e.g. anti-depressive) and dissatisfaction with labour conditions. Obviously, it is difficult to establish a direct link between crisis and health. However the Health Minister, Paulo Macedo, has publically stated several times that the crisis is having an impact on Health.

The precariousness of labour conditions (praised by the troika) and the reduction of advertising revenues have also complicated the already fragile media sector and the journalistic reporting of the crisis. When the economic and financial crisis hit 
the Portuguese media, the hardship was already there. The economic stagnation over the previous decade (since Portugal joined the Eurozone) did not favour the development of alternative business models and the Portuguese media had serious difficulties dealing with the digitalisation and the migration of attention from traditional media to online platforms. Whilst struggling with the new multi-platform environment and increasing fragmentation of attention, the economic and financial crisis has severely deepened the already existing problems particularly via the reduction of advertising revenues.

In addition, the media were exposed to the direct and indirect, overt and covert, investments of Angolan elites in the Portuguese media since 2009 causing much speculation and uncertainty in the newsrooms as ownership and editorial lines frequently became difficult to read for journalists and the public.

Blurred objectives, job insecurity, and the increase of daily pressure due to the reduction of newsrooms created the perfect setting for a less critical journalism. The troika and the "arch of power" discourses were basically absorbed and reproduced by the mainstream media. Alternative discourses did exist but they were either marginalised or framed as radical (anti-patriotic even). Differently from social network movements and street demonstrations, ${ }^{34}$ generalist and economic media have been part of the "manufacture of consent" about the troika's programme.

\section{Notes:}

1. http://www.ionline.pt/artigos/portugal/passos-coelho-critica-comunicacao-social-destacarpode-correr-mal-portugal/pag/-1 (25 March 2014).

2. The title "Porque devemos sair do Euro" might be translated as "'Why should we leave the Euro." The authors are responsible for all translations in this paper.

3. Portugal: Memorandum of Understanding on Specific Economic Policy Conditionality, 3 May 2012 (Agreement signed by the European Commission, European Central Bank and the International Monetary Fund and the Portuguese State). http://www.portugal.gov.pt: accessed in 28 March 2014.

4. INE (Instituto Nacional de Estatística). Destaque, Rendimento e Condições de Vida 2013 (dados Provisórios) 24 March 2014, 1-15.

5. Jornal de Negócios is a daily economic newspaper.

6. Público is a generalist daily newspaper.

7. Diário Económico is daily economic newspaper.

8. Data from The National Statistics Institute and Pordata, INE/Pordata,www.pordata.pt: accessed in 27 April 2014.

9. INE (Instituto Nacional de Estatística). 2014. Destaque, Anuário Estatístico de Portugal 2012. 7 February 2014, 5.

10. INE (Instituto Nacional de Estatística). 2014. Destaque, Anuário Estatístico de Portugal 2012. 7 of February 2014, 5.

11. Portugal: Memorandum of Understanding on Specific Economic Policy Conditionality, 3 May 2012 (Agreement signed by the European Commission, European Central Bank and the International Monetary Fund and the Portuguese State). http://www.portugal.gov.pt: accessed in 28 March 2014.

12. Diário de Notícias is a daily generalista newspaper.

13. Roteiros VIII is published in the President's official site: http://www.presidencia.pt/ accessed in 30 March 2014. 
14. Expresso is a weekly generalist newspaper.

15. Interview to Jornal de Notícias in 21 February 2014 in http://www.jn.pt/live/entrevistas, accessed in 30 March 2014.

16. Electoral official results in http://www.autarquicas2013.pt: accessed in 29 March 2014

17. Interview to TSF in www. tsf.pt: accessed 28 March 2014.

18. In http://www.publico.pt (31 March 2014).

19. http://rr.sapo.pt/informacao_detalhe.aspx?fid=1\&did=143456 (27 March 2014).

20. http://rr.sapo.pt/informacao_detalhe.aspx?fid=27\&did=143469 (28 March 2014).

21. One counter-current example was the publication by Exame of an extensive dossier on the troubles of BPN - a bank nationalised in 2008 with estimated losses for the State exceeding $€ 4$ billion - in its edition of 21 March 2001.

22. Furthermore, a number of journalists who lead these changes (namely in Diário de Notícias) would later leave the profession to occupy positions within the new social-democrat led governmental structure.

23. Between 2004 and 2009 the number of official interns (these only include those under contract with the companies and registered with the professional title awarding entity - CCPJ) rose from 5 percent to 10 percent of the total number of journalists (Rebelo 2011,57). For a perhaps more accurate overview of the situation we should at least add the impact of the curricular internship programmes of more than $30 \mathrm{Ba}$ and $50 \mathrm{MA}$ programmes (with periods ranging from one to six months).

24. http://expresso.sapo.pt/austeridade-tira-29-mil-milhoes-de-euros-aos-portugueses $=f 862270$ (25 March 2014).

25. These figures compare official circulation figures between the first bimester of 2008 and the first bimester of 2013. Available here: http://www.apct.pt/Analise_simples.php (26 March 2014).

26. According to the study conducted by Costa et al these fluent interchanges took 27 former members of Portuguese governments into the boards of companies and groups operating mainly in Angola (strictly Angolan, of Angolan capital majority, of mixed Angolan-Portuguese capital or of Brazilian-Angolan capital), and prompted 120 others to positions in 17 distinct Portuguese economic groups with Angolan capital since 2007.

27. The former Angolan prime minister (1992-1996) and CPLP's first Executive Secretary (19962000) wrote the following on his personal blog: "In Portugal, I see exactly what I predicted.

Businessmen, diplomats and even intellectuals, fall to their knees asking Portuguese newspapers not to touch the little problems of Angolan dignataries, like the world known issues with General Bento Kangamba. For that to be mentioned in France, in Brazil, in the USA or elsewhere is OK, but not here in Portugal, "oh no, please no." (http://marcolinomoco.com/? $\mathrm{p}=888,31$ October 2013).

28. http://www.nytimes.com/slideshow/2012/11/27/world/europe/20121128-PORTUGAL.html\#1 (24 March 2014).

29. http://expresso.sapo.pt/the-new-york-times-mostra-portugal-como-um-paisdesolador=f770510 (24 March 2014).

30. http://krugman.blogs.nytimes.com/2011/01/10/portugal-o-nao/ (25 March 2014).

31. http://www.nytimes.com/2011/05/23/opinion/23krugman. html?scp=1\&sq=Portugal+Krugman\&st=cse (25 March 2014).

32. http://www.jn.pt/Paginalnicial/Economia/Interior.aspx?content_id=2327057 (25 March 2014).

33. http://krugman.blogs.nytimes.com/2013/05/27/nightmare-in-portugal/ (25 March 2014).

34. From March 2011 until March 2013 Portugal had five major massive moments of national uprising, some of them gathering almost one million people in several major cities (a recent national internal security report revealed that 3012 acts of protest were accounted for by police in 2012 and 2859 were registered in 2013). 


\section{References:}

Amaral, Ferreira do. 2013. Porque Devemos Sair do Euro, o divórcio necessário para tirar Portugal da Crise. Alfragide: Lua de papel.

Bastos, Hélder. 2010. Origens e evolução do ciberjornalismo em Portugal: os primeiros quinze anos. Porto: Edições Afrontamento.

Bayart, Jean-François. 1993. The State in Africa - The Politics of the Belly. London: Longman.

Baumgarten, Britta. 2013. Geração à Rasca and beyond: Mobilizations in Portugal after 12 March 2011. Current Sociology 61, 4, 457-473.

Brock, George. 2013. Out of Print - Newspapers, Journalism and the Business of News in the Digital Age. London: Kogan Page.

Campos-Freire, Francisco. 2011. Las nuevas tendencias de gestión de la empresa medática. In F. Campos-Freire (ed.), El nuevo escenario mediático, 109-136. Zamora: Comunicación Social.

Carvalho, Miguel. 2013. Ascenção e queda de Passos, versão 2.0. Visão, 14 November, 48-51.

Costa, Jorge, João Teixeira Lopes, and Francisco Lou-ca 2014. Os donos angolanos de Portugal. Bertrand: Lisboa.

Fernández, Fátima F. 2013. Medios descapitalizados, valores a la baja. Todas las crisis, la crisis. VII International Conference on Communication and Reality. Ramon Llull University, Barcelona, June 13-14, 119-126.

Ferin Cunha, Isabel. 2013. Cobertura jornalística da crise política e financeira e o 'issue' corrupção política. Brazilian Journalism Research 9, 1, 18-37.

Figueiras, Rita and Nelson Ribeiro. 2013. New Global Flows of Capital in Media Industries after the 2008 Financial Crisis: The Angola-Portugal Relationship. International Journal of Press/Politics $18,4,508-524$.

INE (Instituto Nacional de Estatística). 2013. Estatísticas Demográficas 2012. Lisboa: Instituto Nacional de Estatística, IP.

Fragoso, Alberto. 2013. A mediatização da crise financeira no Jornal da Noite da SIC. MA Thesis. Braga: Instituto de Ciências Sociais - Universidade do Minho.

Garcia, José Luís. 2010. Para o estado da arte da investigação sobre os jornalistas portugueses. Media \& Jornalismo 9, 2, 125-150.

Hallin, Daniel C. 1986. The Uncensored War: The Media and Vietnam. New York: Oxford University Press.

Lippman, Walter. 1922/2012. Public Opinion. Mansfield Centre, CT: Martino Publishing.

Lopes, Luís Ferreira. 2009. Seja mais Esperto do que a Crise. Lisboa: A Esfera dos Livros.

Meyer, Phillip. 2004. The Vanishing Newspaper - Saving Journalism in the Information Age. London: University of Missouri Press.

Michalis, Maria. 2011. La politica europea de comunicación y su impacto en los medios de radiodifusión. In F. Campos-Freire (ed.), El nuevo escenario mediático, 29-48. Zamora: Comunicación Social.

Nobre, Adriano. 2014. Media perdem um terço da publicidade em dez anos. Expresso-Economia 23, 22 March.

Queirós, Eça and Ramalho Ortigão. 1873/2004. As Farpas - Crónica mensal da política, das letras e dos costumes. S. João do Estoril: Princípia.

Rebelo, José, ed. 2011. Ser jornalista em Portugal - perfis sociológicos. Lisboa: Gradiva.

Rodrigues, João and José Reis. 2012. The Asymmetries of European Integration and the Crisis of Capitalism in Portugal. Competition and Change 16, 3, 188-205.

Santos, José Eduardo. 2013. Mensagem sobre o Estado da Nação, proferida por Sua Excelência José Eduardo dos Santos, Presidente da República de Angola, na abertura da II Sessão Legislativa da III Legislatura da Assembleia Nacional, 15 October. Luanda. < http://www.mission-angola.ch/ discursos/pt/20131015_presidente_pt.pdf>

Schudson, Michael. 2008. Why Democracies Need an Unlovable Press. Cambridge: Polity Press. 